\title{
PENGEMBANGAN BAHAN AJAR AQIDAH AHKLAK DI MADRASAH IBTIDAIYAH
}

\section{Fitri Erning Kurniawati}

Dinas Pendidikan Kabupaten Sragen, Jawa Tengah, Indonesia Azza_1455@yahoo.co.id

\begin{abstract}
DEVELOPING AKIDAH AKHLAK TEACHING MATERIAL AT MADRASAH IBTIDAIYAH. Teacher has a strategic role in the learning process, can be said that to realize the learning success is teacher responsibility. The learning successit was not yet enough if only measured by how many students who can pass and get a good score, especially in teaching AkidahAkblakstudent must actualize the Islamic values in their real life. This article tried togive the impression how provide the purpose of the AkidahAkblaklearning process, by developing AkidabAkblakteaching materials at the elementary level, without deny the principlesthat must be fulfilled in developing teaching materials.
\end{abstract}

Keywords: Teaching Materials, Akidahakblak, Madrasah

\begin{abstract}
Abstrak
Seorang guru mempunyai peran yang strategis dalam proses pembelajaran, boleh dikata berhasil tidaknya proses pembelajaranmerupakan tanggung jawab penuh seorang guru untuk mewnjudkannya. Keberhasilan proses pembelajaran belum cukup jika hanya diukur dari berapa banyak siswa yang bisa lulus dan mendapatkan nilai yang
\end{abstract}


baik, terutama dalam pembelajaran Aqidah Akblak siswa diharapkan dapat mengaktualisasikan nilai-nilai Islam yang didapatnya dari pembelajaran dalam kebidupan nyata. Tulisan ini mencoba memberi gambaran bagaiamana mewnjudkan tujuan dari proses pembelajaran Aqidah Akblak, dengan cara mengembangkan bahan ajar terkhusus pembelajaran Aqidah Akblak di tingkat dasar, tanpa menyampingkan prinsip-prinsip yang harus dipenubi dalam pengembangan baban ajar.

Kata Kunci: Bahan Ajar, Aqidah Akblak, Madrasah.

\section{A. Pendahuluan}

Media dan sumber pembelajaran merupakan suatu bagian integral dari keseluruhanproses pembelajaran, salah satu persyaratan untuk menjadi guru profesional yaitu guru dapat mengembangkan sumber belajar atau bahan ajar agar pembelajaran tidak berjalan monoton dan membosankan. Dengan media atau bahan ajar yang bagus di harapkan standar kompetensi ataupun kompetensi dasar dapat tercapai.

Usaha dalam meningkatkan kualitas pembelajaran pada dasarnya merupakan kesatuan dalam proses pembelajaran, tidak hanya dalam pemilihan dan penerapan srategi yang tepat, namun ada hal-hal yang perlu diperhatikan antara lain yaitu pemilihan bahan ajar dalam menyajikan proses pembelajaran agar hasil yang didapatkannya optimal dan mencapai target belajar sesuai dengan tujuan pembelajaran yang telah ditetapkan. Dalam kaitan ini, bahan ajarmerupakan salah satu komponen penting dalam pembelajaran, terlebih bahan ajar merupakan sarana pendukung dalam proses pembelajaran.

Salah satu komponen dalam perencanaan pengajaran yang dibuat oleh guru adalah sumber belajar yang didalamnya termasuk bahan ajar yang sering diisi dengan buku-buku atau sumber tertulis lainnya. Inovasi dan pengembangan bahan ajar dalam proses pembelajaran sangat diperlukan, hal ini merupakan tanggung jawab dari seorang pendidik dalam mengembangkannya,karena yang mengetahui secara langsung keadaan siswa atau lingkungan sekitar

${ }^{1}$ Darwyn Syah, Perencanaan Sistem Pengajaran Pendidikan Agama Islam, (Jakarta: Gaung Persada Press. 2007), hlm. 118. 
yaitu seorang guru dalam kaitanya ketersediaan bahan atau sarana dan prasarana yang ada dilingkungan sekolah.

Pembelajaran Aqidah Akhlak di Madrasah Ibtidaiyah merupakan salah satu mata pelajaran PAI yang menekankan pada kemampuan memahami dan mempertahankan keyakinan atau keimanan yang benar, mempelajari bagaimana tata cara berinteraksi dengan manusia (habluminannas) serta hubungan manusia dengan sang khalik (babluminallab). Dengan ini diharapkan siswa tertanam keteladanan dan pembiasaan dalam mengamalkan akhlak terpuji dan adab islami melalui pemberian contoh-contoh perilaku dan cara mengamalkannya dalam kehidupan sehari-hari.

Maka dari itu, materi pendidikan Aqidah Akhlak bukan hanya mengajarkan pengetahuan tentang agama, akan tetapi bagaimana membentuk kepribadian siswa agar memiliki keimanan dan ketakwaan yang kuat dan kehidupanya dihiasi dengan akhlak yang mulia dimanapun mereka berada. Oleh karena itu guru dalam hal ini guru PAI atau guru kelas dituntut untuk mengembangkan bahan ajar sedemikian mungkin agar tujuan dari pembelajaran Aqidah Akhlak dapat terwujud sesuai dengan yang diharapkan.

Pengembangan bahan ajar tidak lepas dari kurikulum karena salah satu unsur atau bagian urgen kurikulum yang utama adalah: bahan ajar. ${ }^{2}$ Guru sebagai seorang yang mengantarkan siswa untuk mencapai tujuan atau kompetensi, maka guru berkewajiban mempersiapkan segala sesuatu termasuk menyusun bahan ajar. Dalam hal menyusun bahan ajar guru harus mengetahui prinsip-prinsip dalam pengembangan bahan ajar, agar bahan ajar yang ada dapat memperlancar dalam proses pembelajaran sehingga bahan ajar yang tercipta dapat berfungsi secara maksimal.

\section{B. Pembahasan}

\section{Bahan Ajar Pembelajaran}

\section{a. Pengertian}

Bahan ajar atau materi pembelajaran (instructional materials) adalah segala sesuatu pengetahuan, sikap maupun ketrampilan yang harus dipelajari seorang peserta didik dalam rangka mencapai

${ }^{2}$ Suyono dan Hariyanto MS, Belajar dan Pembelajaran Teori dan konsep Dasar, (Bandung: Remaja Rosda Karya, 2011), hlm. 207. 
kompetensi inti dan kompetensi dasar yang diharapkan dalam pendidikan. Sedangkan jenis-jenis materi pembelajaran terdiri dari pengetahuan (fakta, konsep, prinsip, prosedur), keterampilan, dan sikap atau nilai. ${ }^{3}$

Bahan ajar juga bisa diartikan sebagai seperangkat materi pembelajaran yg disusun secara sistematis, menampilkan sosok utuh dari kompetensi yg akan dikuasai siswa dalam kegiatan pembelajaran. ${ }^{4}$ Berangkat dari pengertian diatas, maka dapat dipetakan bahwa yang dimaksud dengan Bahan ajar adalah segala bentuk bahan baik berupa secara materi ataupun material yang digunakan untuk membantu guru dalam melaksanakan kegiatan belajar mengajar di kelas.Bahan yang dimaksud bisa berupa bahan tertulis maupun bahan tidak tertulis.

Perlu dibedakan antara bahan ajar dan sumber belajar.sumber belajar adalah segala sesuatu atau daya yang dapat dimanfaatkan oleh guru,segala sesuatu yang dapat memberikan kemudahan belajar, yang darinya diperoleh berbagai informasi, pengetahuan, pengalaman, dan keterampilan yang diperlukan untuk pembelajaran baik secara terpisah maupun dalam bentuk gabungan, untuk kepentingan belajar mengajar dengan tujuan meningkatkan efektivitas dan efisiensi tujuan pembelajaran. ${ }^{5}$ Sedangkan bahan ajar adalah materi yang tertuang atau segala hal yang dapat diambil manfaat dari sumber belajar.

\section{b. Prinsip-prinsip Pengembangan Bahan Ajar}

Prinsip disini dimaksudkan adalah hal-hal yang harus dipenuhi dalam pengembangan atau penyusunan bahan ajar diantaranya yaitu: ${ }^{6}$

1) Mulai dari yg mudah untuk memahami yg sulit, dari yg konkret untuk memahami yg abstrak. Dalam pengembangan bahan ajar perlu diperhatikan muatan yang ada dalam suatu materi,

3 http://mgmpips.wordpress.com/2007/03/02pengertian-bahan-ajarmateri-pembelajaran/ diakses pada tanggal 10 Desember 2013 pukul 22.00 WIB

${ }^{4}$ Mahmud Arif Dalam Perkuliahan S2 Pasca UIN Sunan Kalijaga, handout, tidak diterbitkan, di presentasikan pada tanggal 1 Desember 2013, hlm. 1 .

${ }^{5}$ Arief Sadiman, Pendayagunaan Teknologi Informasi dan Komunikasi untuk Pembelajaran, (Jakarta: Raja Grafindo, 2004), hlm. 23.

${ }^{6}$ MahmudArif Dalam Perkuliahan S2 Pasca UIN Sunan Kalijaga,. hal. 3 . 
sehingga para siswa mudah dalam memahami dan mengerti materi pembelajaran yang sudah disediakan.

2) Mencapai tujuan ibarat naik tangga, setahap demi setahap, akhirnya akan mencapai ketinggian tertentu; pembelajaran adalah suatu proses bertahap dan berkelanjutan. Bahan ajar yang ada dikemas sedemikian mungkin untuk dapat mencapai tujuan dari pembelajaran.

3) Umpan balik positif akan memberikan penguatan terhadap pemahaman siswa. Dalam bahan ajar diberikan latihan-latihan yg perlu dikerjakan siswa, dan hasilnya diberi umpan balik secara positif oleh guru.

4) Motivasi belajar yg tinggi merupakan salah satu faktor penentu keberhasilan belajar. Diantara cara yang bisa dilakukan, bahan ajar memberi banyak contoh, menjelaskan tujuan dan manfaat materi.

5) Mengetahui hasil yang telah dicapai akan mendorong siswa untuk terus mencapai tujuan. Bahan ajar disini dijadikan salah satu alat evaluasi dalam mengetahui perkembangan siswa dalam proses pembelajaran.

\section{c. Jenis-jenis Bahan Ajar}

Ada beberapa jenis bahan ajar jika dilihat dari bagaimana bahan ajar itu dikemas dan disajikan kepada peserta didik dalam proses pembelajaran, setidaknya ada lima kategori yaitu:

1) Cetak : Handout, Buku, modul, LKS, brosur, leaflet, foto, gambar, model, maket. Bahan ajar cetak mempermudah siswa dalam mempelajarinya selain siswa dapat mempelajari disekolah siswa juga dapat mempelajari dirumah, melihat ketersedian bahan yang sangat mudah diperoleh.

2) Dengar :Kaset, radio, piringan hitam, compact disc. Bahan ajar yang satu ini sering kita menyebutnya dengan media audio atau suara yang dihantarkan oleh gelombang udara yang dapat didengar oleh telinga manusia, manfaat dari media audio disini akan meningkatkan daya ingat siswa dalam memahami materi pembelajaran.

3) Pandang (visual) seperti foto, gambar atau maket, media ini hanya bisa dilihat dan memberikan pemehaman kepada siswa jika dalam pembelajaran ada materi yang berkaitan dengan 
objek yang berukuran besar atau sulit bagi siswa untuk melihat secara langsung.

4) Pandang Dengar : VCD, film, media audiovisual mempunyai keunggulan-keunggulan dibandingkan dengan media-media pembelajaran yang ada, media audiovisual dapat meningkatkan retensi ingatan, meningkatkan transfer ilmu dalam pembelajaran. ${ }^{7}$

5) Multimedia Interaktif :Pembelajaranberbasiskomputer, Web, bahan ajar ini mempermudah siswa atau pesera didik yang mempunyai kendala mengenai jarak, maka siswa dapat mengakses materi yang tersedia melalui internet dengan mudah, media ini disebut juga dengan media yang berbasis online/ daring(dalam jaringan).

\section{d. Strategi Penyampaian Bahan Ajar}

Secara garis besarnya, dalam memanfaatkan bahan ajar terdapat dua strategi. ${ }^{8}$

1) Strategi penyampaian bahan ajar oleh Guru

a) Strategi urutan penyampaian simultan yaitu jika guru harus menyampaikan materi pembelajaran lebih daripada satu, maka menurut strategi urutan penyampaian simultan, materi secara keseluruhan disajikan secara serentak, baru kemudian diperdalam satu demi satu (Metode global).

b) Strategi urutan penyampaian suksesif, jika guru harus manyampaikan materi pembelajaran lebih daripada satu, maka menurut strategi urutan panyampaian suksesif, sebuah materi satu demi satu disajikan secara mendalam baru kemudian secara berurutan menyajikan materi berikutnya secara mendalam pula.

c) Strategi penyampaian fakta, jika guru harus manyajikan materi pembelajaran termasuk jenis fakta (nama-nama benda, nama tempat, peristiwa sejarah, nama orang, nama lambang atau simbol.

d) Strategi penyampaian konsep, materi pembelajaran jenis konsep adalah materi berupa definisi atau pengertian.

${ }^{7}$ Arif Sadiman dkk, Media Pendidikan, (Jakarta: PT. Raja Grafindo Persada, 1993), hlm.7.

${ }^{8}$ Depdiknas, Pedoman Memilih dan Menyusun Bahan Ajar.(Jakarta: t.p, 2006), hlm. 23. 
Tujuan mempelajari konsep adalah agar siswa paham, dapat menunjukkan ciri-ciri, unsur, membedakan, membandingkan, menggeneralisasi. Langkah-langkah mengajarkan konsep: Pertama sajikan konsep, kedua berikan bantuan (berupa inti isi, ciri-ciri pokok, contoh dan bukan contoh), ketiga berikan latihan (Exercise) misalnya berupa tugas untuk mencari contoh lain, keempat berikan umpan balik, dan kelima berikan tes;

e) Strategi penyampaian materi pembelajaran prinsip, termasuk materi pembelajaran jenis prinsip adalah dalil, rumus, hukum (law), ayat-ayat Alqur'an.

f) Strategi penyampaian prosedur, tujuan mempelajari prosedur adalah agar siswa dapat melakukan atau mempraktekkan prosedur tersebut, bukan sekedar faham atau hafal. Termasuk materi pembelajaran jenis prosedur adalah langkah-langkah mengerjakan suatu tugas secara urut.

2) Strategi mempelajari bahan ajar oleh siswa

a) Menghafal (verbal parafrase). Ada dua jenis menghafal, yaitu menghafal verbal (remember verbatim) dan menghafal parafrase (remember paraphrase). Menghafal verbal adalah menghafal persis seperti apa adanya. Terdapat materi pembelajaran yang memang harus dihafal persis seperti apa adanya, misalnya nama orang, nama tempat, nama zat, lambang, peristiwa sejarah, nama-nama bagian atau komponen suatu benda, dalil-dalil dalam Alquran atau hadits-hadits nabi. Sebaliknya ada juga materi pembelajaran yang tidak harus dihafal persis seperti apa adanya tetapi dapat diungkapkan dengan bahasa atau kalimat sendiri (hafal parafrase). Yang penting siswa paham atau mengerti, misalnya paham inti akhlakul karimah, akhlakul mahmudah dan bukti akan kekuasaan Allah.

b) Menggunakan atau mengaplikasikan (use). Materi pembelajaran setelah dihafal atau dipahami kemudian digunakan atau diaplikasikan. Jadi dalam proses pembelajaran siswa perlu memiliki kemampuan untuk menggunakan, menerapkan atau mengaplikasikan materi yang telah dipelajari. Penggunaan fakta atau data adalah untuk dijadikan bukti dalam rangka pengambilan keputusan. Penggunaan materi 
konsep adalah untuk menyusun proposisi, dalil, atau rumus. Selain itu, penguasaan atas suatu konsep digunakan untuk menggeneralisasi dan membedakan. Penerapan atau penggunaan prinsip adalah untuk memecahkan masalah pada kasus-kasus lain. Penggunaan materi prosedur adalah untuk dikerjakan atau dipraktekkan. Penggunaan materi sikap adalah berperilaku sesuai nilai atau sikap yang telah dipelajari. Misalnya, siswa selalau menjaga hubungan yang baik sesama teman sekelasnya dan saling membantu setelah mendapatkan pelajaran tentang Akhlakul karimah.

c) Menemukan. Yang dimaksudkan penemuan (finding) di sini adalahmenemukan cara memecahkan masalah-masalah baru dengan menggunakan fakta, konsep, prinsip, dan prosedur yang telah dipelajari. Menemukan merupakan hasil tingkat belajar tingkat tinggi.

d) Memilih di sini menyangkut aspek afektif atau sikap. Yang dimaksudkan dengan memilih di sini adalah memilih untuk berbuat atau tidak berbuat sesuatu. Misalnya memilih membaca novel dari pada membaca tulisan ilmiah. Memilih menaati peraturan lalu lintas tetapi terlambat masuk sekolah atau memilih melanggar tetapi tidak terlambat.

\section{e. Tujuan Pengembangan Bahan Ajar}

1) Menyediakan bahan ajar yang sesuai dengan tuntutan kurikulum dengan tujuan kebutuhan siswa, yakni bahan ajar yang sesuai dengan karakteristik dan setting atau lingkungan sosial siswa.

2) Membantu siswa dalam memperoleh alternatif bahan ajar di samping makalah-makalah teks yang terkadang sulit diperoleh.

3) Memudahkan guru dalam melaksanakan pembelajaran, sekaligus sebagai pedoman dalam mengarahkan aktivitasnya dalam proses pembelajaran diantaranya yaitu:

a) Dengan menggunakan media pembelajaran pesan yang akan dikomunikasikan menjadi jelas dan dapat dipahami

b) Digunakan untuk mengatasi keterbatasan indra, ruang dan waktu

c) Dapat meningkatkan motivasi siswa dalam kegiatan belajar

d) Memungkinkan interaksi langsung antara murid dengan lingkungan dan realita belajar. 
e) Dapat memberikan rangsangan dan pengalaman belajar yang sama dan membangkitkan persepsi yang sama pula walau ada perbedaan pada setiap individu siswa.

4) Sebagai alat ukur atau evaluasi dalam suatu proses pembelajaran, sehingga kemampuan dan pemahaman siswa dapat diketahui. Bahan ajar disini juga dapat dijadikan sebagai pengukuran bagi peserta didik dalam proses pembelajaran, dengan cara mengidentifikasi pemahaman siswa dari latihan-latihan yang ada di bahan ajar.

\section{Pengembangan Bahan Ajar Aqidah Akhlak}

\section{a. Pembelajaran Aqidah Akhlak}

1) Materi Pembelajaran meliputi

Prinsip-prinsip dalam pemilihan materi pembelajaran a) Relevansi

Prinsip relevansi artinya materi pembelajaran hendaknya relevan memiliki keterkaitan dengan pencapaian standar kompetensi dan kompetensi dasar.Relevan disini berarti antara materi pembelajaran dengan standar kompetensi dasar atau kompetensi dasar saling ada keterkaitan, bahan ajar yang ada seharusnya harus dapat mendukung dalam memenuhi target atau tujuan dalam proses pembelajaran.

b) Konsistensi

Prinsipkonsistensi artinya adanya keajegan antara bahan ajar dengan kompetensi dasar yang harus dikuasai siswa. Konsisten disini dimaksudkan dalam target kompetensi dasar yang harus dicapai harus selaras dengan materi pembelajaran yang akan diajarkan, tidak boleh melebihi dari kompetensi dasar yang sudah ditetapkan.

\section{c) Kecukupan}

Prinsipkecukupan artinya materi yang diajarkan hendaknya cukup memadai dalam membantu siswa menguasai kompetensi dasar yang diajarkan.Materi yang disajikan seharusnya memadai dan dapat membantu siswa dalam memenuhi kompetensi dasar yang ditetapkan, materi harus selalu sejalan dan searah dengan standar kompetensi dan kompetensi dasar yang telah ditetapkan. 
Untuk mengembangkan materi pembelajaran guru harus memperhatikan potensi siswa, relevansi dengan karakteristik daerah, tingkat perkembangan fisik, intlektual, emosional, sosial, dan spritual siswa, kebermanfaatan bagi siswa, struktur keilmuan, aktualitas, kedalaman, dan keluasan materi pembelajaran, relevansi dengan kebutuhan siswa dan tuntutan lingkungan dan alokasi waktu. ${ }^{9}$

2) Metode Pembelajaran Aqidah Akhlak

Metode pembelajaran dapat diartikan sebagai model atau pendekatan pembelajaran bergantung pada karakteristik pendekatan atau strategi yang dipilih. Misalnya metode tanya jawab, diskusi, eksperimen dan lain-lain. Maksud istilah pendekatan dalam kajian ini ialah pendekatan terhadap seluruh unsur terkait dalam pembelajaran. ${ }^{10}$

Metode pembelajaran dewasa ini pada umumnya menggunakan pendekatan sistem ( systemapproach). Dengan pendekatan ini pembelajaran dipandang sebagai suatu sistem. Suatu sistem mempunyai sejumlah komponen yang saling berinteraksi dan berhubungan dalam rangka mencapai tujuan. Sistem pembelajaran juga mempunyai sejumlah komponen, yaitu materi, metode, alat, dan evaluasi. Semua komponen itu saling berhubungan dalam rangka mencapai tujuan pembelajaran.

Metode pembelajaran dapat ditetapkan oleh guru dengan memperhatikan tujuan dan materi pembelajaran. ${ }^{11}$ Pertimbangan pokok dalam menentukan metode pembelajaran terletak pada keefektifan proses pembelajaran. ${ }^{12}$ Tentu saja orientasi kita adalah kepada siswa belajar. Jadi metode pembelajaran yang digunakan pada dasarnya hanya berfungsi sebagai bimbingan agar siswa belajar.

Sedangkan metode pembelajaran yang digunakan dalam pembelajaran Aqidah Akhlak menyesuaikan dengan

9 Jamil Suprihatiningrum, Strategi Pembelajaran Teori dan Aplikasi, (Yogyakarta: Arruz Media, 2013), hlm. 302.

${ }^{10}$ Ibid; hlm. 269.

${ }^{11}$ Ramayulis, Metodologi Pengajaran Agama Islam, (Jakarta: Kalam Mulia, 2001), hlm. 2.

${ }^{12}$ Oemar Hamalik, Metode belajar dan Kesulitan-kesulitan Belajar, (Bandung: Tarsito, 1990), hlm. 29. 
materi yang dipelajarinya, karena setiap metode pembelajaran mempunyai kelemahan dan kelebihan masing-masing. Maka disini peran guru dalam memilih dan memilah metode pembelajaran sangat penting karena guru yang mengetahui kekurangan-kekurangan dalam proses pembelajaran.

3) Tujuan Pembelajaran Aqidah Akhlak

Akidah Akhlak di Madrasah Ibtidaiyah merupakan salah satu mata pelajaran PAI yang mempelajari tentang rukun iman yang dikaitkan dengan pengenalan dan penghayatan terhadap al-asma' ul-husna, serta penciptaan suasana keteladanan dan pembiasaan dalam mengamalkan akhlak terpuji dan adab Islami melalui pemberian contoh-contoh perilaku dan cara mengamalkannya dalam kehidupan sehari-hari.

Berdasarkan Permenag No 2 tahun 2008 Mata pelajaran Akidah Akhlak di Madrasah Ibtidaiyah bertujuan untuk membekali peserta didik agar dapat $:^{13}$

a) Menumbuhkembangkan Aqidah melalui pemberian, pemupukan, dan pengembangan pengetahuan, penghayatan, pengamalan, pembiasaan, serta pengalaman peserta didik tentang akidah Islam sehingga menjadi manusia muslim yang terus berkembang keimanan dan ketakwaannya kepada Allah SWT.

b) Mewujudkan manusia yang berakhlak mulia dan menghindari akhlak tercela dalam kehidupan sehari-hari, baik dalam kehidupan individu maupun sosial, sebagai manifestasi dari ajaran dan nilai-nilai akidah islam.

Secara substansial mata pelajaran Akidah Akhlak memiliki kontribusi dalam memberikan motivasi kepada peserta didik untuk mempraktikkan Akhlakul Karimah dan adab Islami dalam kehidupan sehari-hari sebagai manifestasi dari keimanannya kepada Allah, malaikat-malaikat-Nya, kitabkitab-Nya, rasul-rasul-Nya, hari akhir, serta Qada dan Qadar.

Al-akhlak al-karimah ini sangat penting untuk dipraktikkan dan dibiasakan sejak dini oleh peserta didik dalam kehidupan sehari-hari, terutama dalam rangka mengantisipasi

${ }^{13}$ Permenag No 2 tahun 2008 Mata pelajaran Akidah Akhlak. 
dampak negatif era globalisasi dan krisis multidimensional yang melanda bangsa dan Negara Indonesia.

4) Standar Kompetensi (SK) dan Kompetensi Dasar (KD) Mata Pelajaran Akidah Akhlak di Madrasah Ibtidaiyah ${ }^{14}$

\begin{tabular}{lcc}
\hline \multirow{2}{*}{ KELAS } & STANDAR & KOMPETENSI DASAR \\
\hline
\end{tabular}

\begin{tabular}{|c|c|c|}
\hline I Semester I & $\begin{array}{l}\text { 1.Mengenal rukun iman, } \\
\text { syahadat tauhid dan } \\
\text { syahadat rasul, al-asma' } \\
\text { al-husna (al-Ahad dan al- } \\
\text { Khaliq) }\end{array}$ & $\begin{array}{l}\text { 1.1 Menghafal enam rukun iman } \\
\text { 1.2 Menghafal dua kalimat } \\
\text { syahadat } \\
\text { 1.3 Mengartikan dua kalimat } \\
\text { syahadat } \\
\text { 1.4 Mengenal sifat-sifat Allah } \\
\text { (al-Ahad dan al-Khaliq) melalui } \\
\text { kisah Nabi Ibrahim AS mencari } \\
\text { Tuhannya }\end{array}$ \\
\hline $\begin{array}{c}\text { II Semester } \\
\text { I }\end{array}$ & $\begin{array}{l}\text { 1. Memahami kalimat } \\
\text { thayyibah (hamdalah), dan } \\
\text { al-asma' al-husna (ar- } \\
\text { Razzaaq, al-Mughnii, al- } \\
\text { Hamiid, dan asy-Syakuur) }\end{array}$ & $\begin{array}{l}\text { 1.1 Mengenal Allah melalui } \\
\text { kalimat thayyibah (hamdalah) } \\
\text { 1.2 Mengenal Allah melalui } \\
\text { sifat-sifat Allah yang terkandung } \\
\text { dalam al-asma' al-husna (ar- } \\
\text { Razzaaq, al-Mughnii, al-Hamiid, } \\
\text { dan asy-Syakuur) } \\
\text { 1.3 Mengenal Allah melalui } \\
\text { pengenalan terhadap salat lima } \\
\text { waktu }\end{array}$ \\
\hline
\end{tabular}

${ }^{14}$ Kementerian Agama RI, Standar Kompetensi (Sk) Dan Kompetensi Dasar (Kd)Matapelajaran Pendidikan Agama Islam Dan Bahasa Arab Madrasah Ibtidaiyah, (Jakarta: SKKemenag, 2008). 


\begin{tabular}{|c|c|c|}
\hline $\begin{array}{c}\text { III Semester } \\
\text { I }\end{array}$ & $\begin{array}{l}\text { 1.Memahami kalimat } \\
\text { thayyibah (Subhaanallaah, } \\
\text { Maasyaallah), al-asma' } \\
\text { al-husna (al-Mushawwir, } \\
\text { al-Haliim, dan al-Kariim) }\end{array}$ & $\begin{array}{l}\text { 1.1 Mengenal Allah melalui } \\
\text { kalimat thayyibah (Subhanallaah, } \\
\text { Maasyaallah) } \\
\text { 1.2 Mengenal Allah melalui } \\
\text { sifat-sifat Allah yang terkandung } \\
\text { dalam al-asma' al-husna (al- } \\
\text { Mushawwir, al-Haliim, dan } \\
\text { al-Kariim) }\end{array}$ \\
\hline $\begin{array}{c}\text { IV Semester } \\
\text { I }\end{array}$ & $\begin{array}{l}\text { 1. Memahami kalimat } \\
\text { thayyibah (inna lillaahi } \\
\text { wa innaa ilaihi rajiuun) } \\
\text { dan al-asma' al-husna } \\
\text { (al-Mukmin, al-Azhim, } \\
\text { al- Haadii, al-Adlu, dan } \\
\text { al-Hakam) }\end{array}$ & $\begin{array}{l}\text { 1.1 Mengenal Allah melalui } \\
\text { kalimat thayyibah (inna lillaahi } \\
\text { wa innaa ilaihi rajiuun) } \\
\text { 1.2 Mengenal Allah melalui } \\
\text { sifat-sifat Allah yang terkandung } \\
\text { dalam al-asma' al-husna (al- } \\
\text { Mukmin, al-Azhim, al- Haadii, } \\
\text { al-Adlu, dan al-Hakam) }\end{array}$ \\
\hline $\begin{array}{c}\text { V semester } \\
\text { I }\end{array}$ & $\begin{array}{l}\text { 1. Memahami kalimat } \\
\text { thayyibah (Alhamdulillaah } \\
\text { dan Allahu Akbar), } \\
\text { al-asma' al-husna (al- } \\
\text { Wahhaab, ar-Rozzaaq, al- } \\
\text { Fattaah, asy-Syakuur, dan } \\
\text { al-Mughni) }\end{array}$ & $\begin{array}{l}\text { 1.1 Mengenal Allah } \\
\text { melalui kalimat thayyibah } \\
\text { (Alhamdulillaah dan Allahu } \\
\text { Akbar) } \\
\text { 1.2 Mengenal Allah melalui } \\
\text { sifat-sifat Allah yang terkandung } \\
\text { dalam al-asma' al-husna } \\
\text { (al-Wahhaab, ar-Rozzaaq, } \\
\text { al-Fattaah, asy-Syakuur, dan } \\
\text { al-Mughni) }\end{array}$ \\
\hline $\begin{array}{c}\text { VI Semester } \\
\text { I }\end{array}$ & $\begin{array}{l}\text { 1. Mengenal } \\
\text { kalimat thayyibah } \\
\text { (astaghfirullaahal'aziim) } \\
\text { dan al-asma' al-husna } \\
\text { (al-Qawwiy, al-Hakim, al- } \\
\text { Mushawwir dan al-Qadir) }\end{array}$ & $\begin{array}{l}\text { 1.1 Mengenal Allah } \\
\text { melalui kalimat thayyibah } \\
\text { (astaghfirullaahal'aziim) } \\
\text { 1.2 Mengenal Allah melalui } \\
\text { sifat-sifat Allah yang terkandung } \\
\text { dalam al-asma' al-husna } \\
\text { (al-Qawwiy, al-Hakim, al- } \\
\text { Mushawwir dan al-Qadir) }\end{array}$ \\
\hline
\end{tabular}




\section{b. Langkah-langkah Pengembangan Bahan Ajar Aqidah Akhlak}

1) Analisa Kebutuhan Bahan

Untuk mendapatkan bahan ajar yang sesuai dengan tuntutan kompetensi yang harus dikuasai oleh peserta didik, diperlukan analisis SK-KD, analisis sumber belajar, dan penentuan jenis serta judul bahan ajar. ${ }^{15}$

a) Analisis $S K-K D$

Analisis SK-KD dilakukan untuk menentukan kompetensi-kompetensi mana yang memerlukan bahan ajar. Dari hasil analisis ini akan dapat diketahui berapa banyak bahan ajar dan jenis bahan ajar yang akan disiapkan dalam proses pembelajaran.

Dalam menyusun bahan yang perlu diperhatikan adalah bahwa judul atau materi yang disajikan harus berintikan $\mathrm{KD}$ atau materi pokok yang harus dicapai oleh peserta didik.

Contoh Analisis SK-KD dalam pembelajaran Aqidah Akhlak di MI.

Mata pelajaran : Aqidah Akhlak

Kelas : I

Semester : I

Standar Kompetensi: Mengenal rukun iman, syahadat tauhid dan syahadat rasul.

\begin{tabular}{|c|c|c|c|c|}
\hline $\begin{array}{l}\text { Kompetensi } \\
\text { Dasar }\end{array}$ & Indikator & $\begin{array}{l}\text { Materi } \\
\text { pembelajaran }\end{array}$ & $\begin{array}{l}\text { Kegiatan } \\
\text { pembelajaran }\end{array}$ & $\begin{array}{l}\text { Bahan } \\
\text { ajar }\end{array}$ \\
\hline $\begin{array}{l}\text { Menghafal } \\
\text { enam rukun } \\
\text { iman, } \\
\text { Menghafal } \\
\text { dua kalimat } \\
\text { syahadat, } \\
\text { Mengartikan } \\
\text { dua kalimat } \\
\text { syahadat }\end{array}$ & $\begin{array}{l}\text { 2. Membedakan } \\
\text { syahadat rosul } \\
\text { dan syahadat } \\
\text { tauhid }\end{array}$ & $\begin{array}{l}\text { 1. Rukun } \\
\text { iman } \\
\text { 2. Kalimat } \\
\text { syahadatain }\end{array}$ & $\begin{array}{l}\text { Menghafal } \\
\text { rukun iman } \\
\text { dengan } \\
\text { nyanyian. } \\
\text { Menghafal } \\
\text { syahadatain } \\
\text { dengan cara } \\
\text { setoran } \\
\text { kepada teman } \\
\text { sebangku }\end{array}$ & $\begin{array}{l}\text { Buku, } \\
\text { LKS }\end{array}$ \\
\hline
\end{tabular}

${ }^{15}$ Departemen Pendidikan Nasional, Panduan Pengembangan Bahan Ajar, (Jakarta: Direktorat Pendidikan Menengah Atas, 2008), hlm. 18. 
Kebutuhan bahan ajar akan dapat dilihat dari analisis di atas, jenis bahan ajar dapat diturunkan dari pengalaman belajarnya. Semakin jelas pengalamn belajar diuraiakan maka akan diketahui kelebihan dan kekurangan bahan ajar yang sudah di sajikan, dengan begitu guru akan mengidentifikasi dan melengkapi dari kekurangan bahan ajar yang ada.

\section{b) Analisa Sumber Belajar}

Sumber belajar yang akan digunakan dalam penyusunan bahan ajar perlu di lakukan analisis. Analisis dilakukan terhadap ketersedian, kesesuaian dan kemudahan dalam memanfaatkannya.Caranyayaitu menginventarisasi ketersedian sumber belajar yang dikaitkan dengan kebutuhan. ${ }^{16}$

Dalam hal pengembangan bahan ajar Aqidah Akhlak ditingkat Madrasah Ibtidaiyah perlu diperhatikan dalam penyedian dan asas kemanfaatan dari sumber belajar untuk mengembangkan bahan ajar diantara yang harus diperhatikan dalam mengemas bahan ajar.

a) Susunan tampilan, yang menyangkut: Urutan yang mudah, judul yang singkat, terdapat daftar isi, struktur kognitifnya jelas, rangkuman, dan tugas pembaca.

b) Bahasa yang mudah, menyangkut: mengalirnya kosa kata, jelasnya kalimat, jelasnya hubungan kalimat, kalimat yang tidak terlalu panjang.

c) Menguji pemahaman, yang menyangkut: menilai melalui orangnya, check list untuk pemahaman.

d) Stimulan, yang menyangkut: enak tidaknya dilihat, tulisan mendorong pembaca untuk berfikir, menguji stimulan.

e) Kemudahan dibaca, yang menyangkut: keramahan terhadap mata (huruf yang digunakan tidak terlalu kecil dan enak dibaca), urutan teks terstruktur, mudah dibaca.

f) Materi instruksional, yang menyangkut: pemilihan teks, bahan kajian, lembar kerja (work sheet).

c) Pemiliban dan Penentuan Bahan Ajar

Pemilihan dan penentuan bahan ajar dimaksudkan untuk memenuhi salah satu kriteria bahwa bahan ajar harus menarik, dapat membantu siswa dalam mencapai kompetensi.

${ }^{16}$ Ibid, hal. 19. 
Sehingga bahan ajar dibuat sesuai dengan kebutuhan dan kecocokan dengan KD yang akan diraih oleh peserta didik. Jenis dan bentuk bahan ajar harus ditetapkan atas dasar analisis kurikulum dan atas dasar analisis bahan ajar sebelumnya.

2) Menyusunan Peta Bahan Ajar

Peta kebutuhan bahan ajar disusun setelah diketahui berapa banyak bahan ajar yang harus disiapkan melalui analisis kebutuhan bahan ajar. Peta Kebutuhan bahan ajar sangat diperlukan guna mengetahui jumlah bahan ajar yang harus ditulis dan sekuensi atau urutan bahan ajarnya seperti apa. Sekuensi bahan ajar ini sangat diperlukan dalam menentukan prioritas penulisan. Di samping itu peta dapat digunakan untuk menentukan sifat bahan ajar, apakah dependen (tergantung) atau independen (berdiri sendiri). ${ }^{17}$

Bahan ajar dependen adalah bahan ajar yang ada kaitannya antara bahan ajar yang satu dengan bahan ajar yang lain, sehingga dalam penulisannya harus saling memperhatikan satu sama lain, apalagi kalau saling mempersyaratkan. Sedangkan bahan ajar independen adalah bahan ajar yang berdiri sendiri atau dalam penyusunannya tidak harus memperhatikan atau terikat dengan bahan ajar yang lain. ${ }^{18}$ Sebagai contoh peta bahan ajar untuk Aqidah Akhlak MIKelas semester I Peta diambil dari SK nomor I, KD nomor 1, dimana materi pokok sebagai judul bahan ajar.

3) Contoh bahan ajar Aqidah Akhlak

Bahan ajar cetak dapat berupa handout, makalah, lembar kegiatan siswa (LKS), modul, brosur atau leaflet, Wallchart, Foto atau Gambar, Model atau Maket. Dalam makalah ini akan ditampilkan contoh bahan ajar Aqidah Akhlak yang dalam pembelajaran Madrasah Ibtidaiyah dalam bentuk cetak yang berupa LKS kelas lima.

Lembar Kegiatan Siswa (studentworksheet) adalah lembaran-lembaran berisi tugas yang harus dikerjakan oleh peserta didik. Lembar kegiatan siswa akan memuat paling tidak; judul, KD yang akan dicapai, waktu penyelesaian, peralatan atau

${ }^{17}$ Lanjar Pramudi. Lembaga Penjaminan Mutu Pendidikan (Bengkulu: LPMP, 2008), hlm. 8.

${ }^{18}$ Ibid, hlm. 9. 
bahan yang diperlukan untuk menyelesaikan tugas, informasi singkat, langkah kerja, tugas yang harus dilakukan, dan laporan yang harus dikerjakan.

Struktur LKS secara umum adalah sebagai berikut: Judul, petunjuk belajar (petunjuk siswa), kompetensi yang akan dicapai, informasi pendukung atau materi ajar, tugas-tugas dan langkah-langkah kerja, penilaian.

\section{CONTOH BAHAN AJAR CETAK LKS AQIDAH AKHLAK KELAS V SEMESTER II KALIMAH TAYIBAH}

1. Standar Kompetensi: Memahami kalimat tayyibah (tarji')

2. 1. Mengenal Allah melalui kalimat tayyibah (tarji') RINGKASAN MATERI

A. Pengertian Kalimat Tayyibah Tarji'

Agama islam mengajarkan agar segala ucapan yang keluar dari

kedua bibir kita adalah ucapan yan baik dan mulia. Mengucapkan kata-kata yang baik harus dilakukan kapan saja dalam keadaan senang maupun susah.

Lafal kalimah tayibah: INNALILAHI WAINNA LILAHIRAJIUN

Artinya: Sesungguhnya kami adalah milik Allah dan kepadaNya lah kami akan kembali.

Barang siapa yang terkena musibah kemudian ia mengucapkan kalimat tarji' kemudian bersabar, maka Allah akan memberikan ganti yang lebih baik. Dan Allah akan memberi keutamaan-keutamaan bagi orang yang sabar dan ihklas atas musibah yang menimpa dirinya.

B. Perilaku Menghadapi Musibah

Di dunia tidak ada satu musibah pun yang terlewatkan dari pengetahuan Allah. Seperti kecelakaan pesawat, kapal tenggelam, tanah longsor, banjir, gempa bumi, gelombang tsunami, tabrakan dan lain-lain.

Sikap manuisa menghadapi musibah:

1. Bagi manusia yang tidak beriman musibah merupakan hal yang menyengsarakan dan mendatangkan pende- 
ritaan, bahkan diangkap sebagai siksaan dan seolaholah kiamat.

2. Bagi seorang yang beriman, musibah disikapi sebagai ujian dan cobaan.

3. Bagi orang yang lalai adalah sebagai azab, karena sudah melupakan kewajiban kepada Allah.

Ciri-ciri orang yang sabar dan ikhlas dalam menghadapi musibah yaitu:

1. Tidak menggerutu

2. Tidak mencari-cari kesalahan

3. Tidak putus asa

4. Tetap usaha dan ikhtiar

5. Tawakal kepada Allah

Keutamaan Membaca Kalimat Tarji'

1. Diangkat derajatnya di sisi Allah

2. Diampuni Dosa-dosanya

3. Diberi ketenangan hati oleh Allah

4. Akan di beri rezki yang tidak akan diduga-duga

\section{UJI KOMPETENSI I}

I.Berilab tanda silang $(X)$ pada buruf $a, b, c$, atau pada jawaban yang benar!

1) Sikap orang islam dalam menghadapi musibah adalah...

a) Bersabar

b) Marah-marah

c) Menangis terus

d) Menggerutu

2) Arti kalimat tayyibah adalah...

a) Ucapan yang baik

b) Perkataan tentang Allah

c) Ucapan seseorang

d) Pemujaan-pemujaan

3) Kenikmatan dan musibah berasal dari Allah yang diberikan kepada manusia sebagai...
a) Hukuman
b) Ujian
c) Siksaan
d) Azab 
4) Bagi orang kafir musibah merupakan...
a) Siksaan
b) Cobaan
c) Ujian
d) Kiamat

5) Jika kita mendapat musibah hendaknya mengucapkan kalimat...
a) takbir
b) tahmid
c) tarji'
d) tasbih

II. Isilah titik-titik dibawah ini dengan jawaban yang tepat!

1. Bagi orang muslim musibah merupakan ..... Allah

2. Lillahi artinya....

3. Seseorang muslim harus bersikap...........dalam menerima musibah

4. Azab Allah hanya diberikan kepada orang yang.......

5. Innalilahi wainnailaihirojiun adalah kalimat ......

III. Jawablab pertanyaan-pertanyaan dibawah ini dengan jawaban yang benar!

1. Tulislah kalimat tarji!!

2. Sebutkan keutamaan-keutamaan orang yang sabar dan ikhlas dalam menerima musibah!

3. Tulislah hadits yang diriwayatkan muslim mengenai pentingnya memberi salam!

4. Berilah contoh perilaku dalam menghadapi musibah!

5. Kalimat tarji' di ucapkan pada saat!

\section{Simpulan}

Dari pembahasan diatas Bahan AjarBahan ajar disusun dengan tujuan menyediakan bahan ajar yang sesuai dengan tuntutan kurikulum dengan mempertimbangkan kebutuhan peserta didik, yakni bahan ajar yang sesuai dengan karakteristik dan setting atau lingkungan sosial peserta didik. Di samping itu pengembangan bahan ajar diharapkan dapat membantu peserta didik dalam memperoleh alternatif bahan ajar di samping buku-buku teks yang terkadang sulit 
diperoleh serta memudahkan guru dalam melaksanakan tugasnya sebagai seorang pendidik.

Sedangkan jenis-Jenis Bahan Ajar yang ada antaralain bahan ajar cetak,bahan ajar pandang (visual), bahan ajar dengar (audio), bahan ajar pandang dengar (audio visual), bahan ajar multimedia interaktif (interactiveteachingmaterial).

Dalam pengembangan bahan ajar haruslahmengacu pada prinsip-prinsip dalam pengembangannya.Pengembangan bahan ajar haruslah di mulai dari yang mudah untuk memahami yang sulit, dariyang kongkret untuk memahami yang abstrak, harus dapat memotivasi siswa dalam proses pembelajaran, dan dapat menjadi umpan balik positif akan memberikan penguatan terhadap pemahaman peserta didik.

Dalam mengembangkan bahan ajar perlu diperhatikan stuasi yang ada dalam proses pembelajaran, baik lingkungan sekolah maupun perkembangan siswa. Terkait dengan lingkungan sekolah menyesuaikan dengan sarana dan prasarana yang ada agar bahan ajar yang tidak terkendala dengan masalah teknis. Sedangkan dalam hal perkembangan siswa yang perlu diperhatikan yaitu faktor psikologis siswa dan aspek-aspek yang berkaitan dalam perkembangan siswa dalam proses pembelajaran.

Bahan ajar yang baik adalah bahan ajar yang benar-benar berfungsi secara maksimal dalam proses pembelajaran sehingga tujuan dari pembelajaran itu sendiri dapat tercapai, maka dari itu bahan ajar haruslah sesimpil mungkin dapat dimengerti dan difahami oleh peserta didik bukan malah sebaliknya membuat siswa semakin bingung dengan bahan ajar yang ada karena pengajar kurang piawai dalam mengemasnya. 


\section{DAFTAR PUSTAKA}

Departemen Pendidikan Nasional, Panduan Pengembangan Bahan Ajar, (Jakarta: Direktorat Pendidikan Menengah Atas, 2008). Pedoman Memilih dan Menyusun Bahan Ajar. Jakarta, t.p, 2006.

Hamalik, Oemar, Metode belajar dan Kesulitan-kesulitan Belajar, Bandung: Tarsito, 1990.

http://mgmpips.wordpress.com/2007/03/02pengertian-bahan-ajarmateri-pembelajaran/ diakses pada tanggal 10 Desember 2013 pukul 22.00 WIB

Kementerian Agama RI, Standar Kompetensi (Sk) Dan Kompetensi Dasar (Kd)Matapelajaran Pendidikan Agama Islam Dan Babasa Arab Madrasah Ibtidaiyah, (Jakarta: SKKemenag, 2008).

Mahmud Arif Dalam Perkuliahan S2 Pasca UIN Sunan Kalijaga, tidak diterbitkan, di presentasikan pada tanggal 1 Desember 2013.

Permenag No 2 tahun 2008 Mata pelajaran Akidah Akhlak.

Pramudi, Lanjar, Lembaga Penjaminan Mutu Pendidikan, Bengkulu: LPMP, 2008.

Ramayulis, Metodologi Pengajaran Agama Islam, Jakarta: Kalam Mulia, 2001.

Sadiman, Arief, Pendayagunaan Teknologi Informasi dan Komunikasi untuke Pembelajaran, Jakarta: Raja Grafindo, 2004.

Sadiman, Arif, Media Pendidikan, Jakarta: PT. Raja Grafindo Persada, 1993.

Suprihatiningrum, Jamil, Strategi Pembelajaran Teori dan Aplikasi, Yogyakarta: Arruz Media, 2013.

Suyono dan Hariyanto MS, Belajar dan Pembelajaran Teori dan konsep Dasar, Bandung: Remaja Rosda Karya, 2011.

Syah, Darwyn, Perencanaan Sistem Pengajaran Pendidikan Agama Islam, Jakarta: Gaung Persada Press. 2007. 
